\title{
OPTN wt Allele
}

National Cancer Institute

\section{Source}

National Cancer Institute. OPTN wt Allele. NCI Thesaurus. Code C119641.

Human OPTN wild-type allele is located in the vicinity of $10 \mathrm{p} 13$ and is approximately $39 \mathrm{~kb}$ in length. This allele, which encodes optineurin protein, is involved in both Golgi maintenance and neuronal survival. Mutation of the gene is associated with both amyotrophic lateral sclerosis 12 and open angle glaucoma $1 \mathrm{E}$. 